\title{
Pengaruh iradiasi Gamma terhadap kandungan nutrien, fenol dan aktivitas biologis tanin daun nangka (Artocarpus heterophyllus)
}

\author{
Teguh Wahyono ${ }^{1, *}$, Yunida Maharani ${ }^{1}$, Dedi Ansori ${ }^{1}$, Shintia Nugrahini Wahyu Hardani ${ }^{1}$, \\ Sandra Hermanto ${ }^{2}$, Wahidin Teguh Sasongko ${ }^{1}$, Faiz Nur Faiqoh ${ }^{2}$ \\ ${ }^{1}$ Bidang Pertanian, Pusat Aplikasi Isotop dan Radiasi, Badan Tenaga Nuklir Nasional, Jakarta Selatan, 12440 \\ ${ }^{2}$ Fakultas Sains dan Teknologi, Universitas Islam Negeri Syarif Hidayatullah, Jakarta, 15412 \\ *Correspondence: teguhwahyono@batan.go.id
}

Received: April 1 ${ }^{\text {th }}, 2020$; Accepted: September 25 ${ }^{\text {th }}, 2020$; Published online: November $26^{\text {th }}, 2020$

Abstrak

Tujuan: Penelitian ini bertujuan untuk mengevaluasi pengaruh iradiasi gamma terhadap kandungan nutrien, fenol dan aktivitas biologis tanin daun nangka (Artocarpus heterophyllus). Aktivitas biologis yang dimaksud adalah kemampuan tanin dalam mengikat protein yang terkandung dalam substrat pakan.

Metode: Perlakuan penelitian adalah: DN (daun nangka tanpa iradiasi gamma); DN 5 (daun nangka yang diiradiasi gamma pada dosis $5 \mathrm{kGy}$ ); DN 7,5 (daun nangka yang diiradiasi gamma pada dosis 7,5 kGy) dan DN 10 (daun nangka yang diiradiasi gamma pada dosis $10 \mathrm{kGy}$ ). Variabel yang diamati adalah profil nutrien, fraksi serat, anti nutrien dan aktivitas biologis tanin. Pada pengujian aktivitas biologis tanin, keempat perlakuan ditambahkan polietilen glikol (PEG) sebagai agen inaktivasi tanin. Rancangan Acak Lengkap (RAL) dengan lima ulangan digunakan dalam penelitian ini.

Hasil: Hasil penelitian menunjukkan bahwa iradiasi gamma tidak memberikan pengaruh yang nyata terhadap kandungan bahan organik (BO), protein kasar (PK), acid detergent fiber (ADF), total phenol dan total tanin pada daun nangka. Iradiasi gamma justru menurunkan aktivitas biologis tanin yang direpresentasikan oleh produksi gas kumulatif in vitro. Walaupun demikian, dosis iradiasi gamma 5; 7,5 dan 10 kGy mampu menurunkan kandungan lemak kasar (LK) daun nangka berturut-turut sebesar 57,82; 83,64 dan 97,09\% dari kandungan awal.

Kesimpulan: Kesimpulan penelitian ini adalah Aktivitas biologis tanin pada daun nangka menurun setelah diiradiasi gamma pada dosis > 5 kGy. Dosis iradiasi gamma 7,5 kGy mampu meningkatkan produksi gas komulatif dan kecernaan bahan organik in vitro daun nangka.

Kata Kunci: Aktivitas biologis; Daun nangka; Iradiasi gamma; Tanin

\section{Abstract}

Objective: This experiment aimed to evaluate the effect of gamma irradiation on nutrient, phenol content and tannin biological activity of jackfruit leaves (Artocarpus heterophyllus). The ability of tannin for protein bypass is the meaning of the biological activity.

Methods: Treatments were: DN (jackfruit leaves without gamma irradiation); DN 5 (jackfruit leaves after gamma irradiation at $5 \mathrm{kGy}$ dose); DN 7,5 (jackfruit leaves after gamma irradiation at 7,5 kGy dose) and DN 10 (jackfruit leaves after gamma irradiation at $10 \mathrm{kGy}$ dose). Nutrient profile, fiber 
fraction content, anti nutrient compounds and tannin biological activity were observed in this experiment. Polyethylene glycol (PEG) was added in tannin biological activity procedure as tannin inactivating agent. Completely randomized design with five replications was used in this study.

Results: The results showed that gamma irradiation had no significant effect on organic matter (OM), crude protein (CP), acid detergent fiber (ADF), total phenol and total tannin content on jackfruit leaves. Gamma irradiation actually reduces the biological activity of tannin which is represented by cumulative in vitro gas production. Nevertheless, the doses of 5, 7.5 and $10 \mathrm{kGy}$ could reduce ether extract (EE) content by $57.82 ; 83.64$ and $97.09 \%$ respectively.

Conclusions: It was concluded that the biological activity of tannin could decrease after gamma irradiation treatment at $>5 \mathrm{kGy}$ doses. The $7.5 \mathrm{kGy}$ gamma irradiation dose could increase cumulative gas production and in vitro organic matter digestibility of jackfruit leaves.

Keywords: Biological activity; Gamma irradiation; Jackfruit leaves; Tannin

\section{PENDAHULUAN}

Daun nangka (Artocarpus heterophyllus) adalah tanaman khas tropis yang sering digunakan sebagai hijauan pakan ruminansia oleh peternak rakyat di Indonesia. Sasongko et al [1] melaporkan bahwa daun nangka mengandung total phenol, tanin dan tanin terkondensasi berturut-turut sebesar 10,63; 7,08 dan 5,57\%. Wahyono et al [2] melaporkan bahwa daun nangka adalah sumber tanin yang berpotensi digunakan sebagai agen bypass protein di Indonesia. Hal tersebut disebabkan oleh ketersediaan dan keberadaannya yang cukup familiar bagi peternak rakyat. Bypass protein adalah istilah mekanisme perlindungan terhadap bahan pakan maupun hijauan sumber protein agar lebih efektif dimanfaatkan oleh ternak ruminansia. Tanin memiliki kemampuan dalam melindungi pakan yang mengandung kadar protein tinggi, baik secara kualitas maupun kuantitas. Tanin akan membentuk ikatan kompleks dengan protein untuk melindunginya dari degradasi oleh mikroba rumen. Ikatan tanin-protein selanjutnya akan lepas pada $\mathrm{pH}$ rendah di abomasum, kemudian protein akan didegradasi oleh enzim pepsin [3]. Getachew et al [4] juga melaporkan bahwa ikatan tanin-protein akan stabil dan bertahan pada $\mathrm{pH}$ 3,5 - 7 kemudian akan terurai pada $\mathrm{pH}$ yang lebih rendah di abomasum dan interior duodenum. Hal tersebut akan meningkatkan proporsi ketersediaan asam amino dari bahan pakan sumber protein pada penyerapan pasca rumen.
Aktivitas tanin sebagai anti nutrien dapat ditingkatkan dengan perlakuan iradiasi gamma. Iradiasi gamma memiliki daya penetrasi yang tinggi untuk merubah komposisi nutrien maupun anti nutrien pada objek materi. Iradiasi gamma adalah perlakuan fisik yang aman dan efektif digunakan sebagai agen dekontaminasi mikroba, disinfektan serta meningkatkan kualitas nutrien komoditas pertanian [5]. Santos et al [6] melaporkan bahwa iradiasi gamma pada dosis 7,5 kGy mampu meningkatkan kandungan total phenol dan total tanin daun jambu monyet (Anacardium occidentale) berturut-turut sebesar 10,22 dan $14,57 \%$ dari asalnya. Iradiasi gamma 7,5 kGy juga mampu meningkatkan kadar tanin benalu teh sebesar 18,28\% dibandingkan kontrol [7]. Dosis iradiasi gamma yang bervariasi juga dapat meningkatkan kandungan anti nutrien pada legume liar (Vigna aconitifolia (Jacq.) Marechal) [8], teh Bulgaria [9] dan kulit kacang [10].

Tingkat radiosensitivitas komoditas tanaman untuk merubah komposisi anti nutrien berbeda antar spesies. Berdasarkan beberapa riset sebelumnya, perubahan komposisi anti nutrien terjadi pada dosis radiasi 2,5 - $10 \mathrm{kGy}$. Riset terkait dosis yang tepat dan pengaruh iradiasi gamma terhadap profil nutrien dan anti nutrien pada daun nangka belum pernah dilakukan. Penelitian ini bertujuan untuk mengevaluasi pengaruh iradiasi gamma terhadap kandungan nutrien, anti nutrien dan aktivitas biologis tanin daun nangka, serta mengetahui dosis yang tepat untuk meningkatkan aktivitas biologis tanin daun nangka. 


\section{MATERI DAN METODE}

\section{Persiapan bahan}

Daun nangka diperoleh dari pohon nangka (Artocarpus heterophyllus) di Kawasan Nuklir Pasar Jumat, Cilandak, Jakarta Selatan. Pohon nangka berumur $>10$ tahun yang ditanam pada tanah jenis latosol. Daun nangka yang telah dikoleksi, dianginanginkan kemudian dikeringkan pada oven $60^{\circ} \mathrm{C}$ selama $48 \mathrm{jam}$. Daun yang telah kering kemudian digiling sampai berukuran mesh 35 $( \pm 0,5 \mathrm{~mm})$.

\section{Iradiasi gamma}

Serbuk daun nangka yang telah dikemas dalam kertas karton kemudian diiradiasi gamma di Fasilitas Iradiator Panorama Serbaguna (IRPASENA) Pusat Aplikasi Isotop dan Radiasi (PAIR), Badan Tenaga Nuklir Nasional (BATAN). Dosis radiasi yang digunakan adalah 5; 7,5 dan $10 \mathrm{kGy}$. Sumber radiasi berasal dari Cobalt (Co-60).

\section{Analisis nutrien, fraksi serat dan anti nutrien}

Kandungan nutrien yang meliputi bahan organik (BO), abu, protein kasar (PK) dan lemak kasar (LK) dianalisis berdasarkan metode dalam AOAC [11]. Fraksi serat meliputi neutral detergent fiber (NDF) dan acid detergent fiber (ADF) dianalisis menggunakan metode Van Soest et al [12]. Hemiselulosa ditentukan dengan menghitung selisih fraksi NDF dengan ADF. Fraksi non fiber carbohydrate (NFC) ditentukan menggunakan rumus:

$$
\mathrm{BO}-\mathrm{NDF} \text { - PK - LK [13]. }
$$

Anti nutrien yang meliputi kandungan total phenol dan total tanin dianalisis berturut turut menggunakan metode Folin Ciocalteu [14] dan Makkar [15].

\section{Pengukuran aktivitas biologis tanin}

Pengukuran aktivitas biologis tanin dilakukan dengan menggunakan teknik inkubasi in vitro berdasarkan Menke et al [16]. Penambahan polietilen glikol (PEG; bobot molekul 6000; Sigma-Aldrich) sebanyak 750 mg pada setiap sampel dilakukan berdasarkan prosedur dalam Jayanegara dan Sofyan [3]. Cairan rumen diperoleh dari lima ekor domba lokal betina dengan menggunakan teknik oral stomach tube (OST) [17]. Domba tersebut mengkonsumsi ransum dengan komposisi rumput lapangan dan konsentrat (60:40 dalam \% BK). Cairan rumen yang diambil pada pagi hari sebelum pemberian pakan, disaring menggunakan kain nilon empat lipatan kemudian ditambahkan dalam buffer tereduksi. Medium rumen-buffer dialiri dengan gas $\mathrm{CO}_{2}$ selama 15 menit sebelum dimasukkan ke dalam syringe glass fortuna ${ }^{\circledR}$ kapasitas $100 \mathrm{ml}$. Sebanyak $200 \mathrm{mg}$ sampel dimasukkan ke dalam syringe, dengan atau tanpa penambahan PEG kemudian ditutup dengan piston yang sebelumnya diolesi dengan vaselin. Sebanyak $30 \mathrm{ml}$ cairan rumen-buffer dimasukkan ke dalam syringe glass kemudian diinkubasi ke dalam waterbath incubator bersuhu $39^{\circ} \mathrm{C}$. Produksi gas total diamati pada jam ke-0, 3, 6, 9, 12 dan 24. Profil fermentasi rumen diamati setelah sampel diinkubasi selama 24 jam. Nilai pH diukur menggunakan pH meter Hanna Instrument ${ }^{\circledR}$. Konsentrasi $\mathrm{NH}_{3}$ dianalisis menggunakan prosedur mikrodifusi Conway [18].

Produksi VFA total diestimasi berdasarkan produksi gas total 24 jam menggunakan persamaan Makkar [19]. Kecernaan $\mathrm{BO}(\mathrm{KcBO})$ dan energi yang termetabolis (EM) juga diestimasi berdasarkan kandungan abu dan PK sampel serta produksi gas total 24 jam [20]. Persamaan yang digunakan adalah sebagai berikut:

$$
\begin{aligned}
\mathrm{KcBO}(\%) & =4,88+0,889 \text { gas }+0,45 \mathrm{PK}+0,0651 \mathrm{abu} \\
\mathrm{EM}(\mathrm{MJ} / \mathrm{kg} \mathrm{BK}) & 2,20+0,136 \mathrm{Gas}+0,057 \mathrm{PK} \text { (hasil EM dikonversi } \\
& \text { menjadi kkal } / \mathrm{kg} \mathrm{BK})
\end{aligned}
$$

VFA total (mmol; tanpa PEG) $\quad=0,0239$ gas $-0,0601$

VFA total (mmol; dengan PEG) $=0,0207$ gas $-0,0207$ (hasil VFA total dikonversi menjadi $\mathrm{mM}$ ) 


\section{Rancangan percobaan}

Data profil nutrien, fraksi serat dan fenol yang dianalisis berasal dari empat perlakuan dan lima pengulangan. Unit percobaan/ulangan adalah kemasan sampel daun nangka pada saat diiradiasi gamma. Perlakuan yang dimaksud adalah: DN (daun nangka tanpa iradiasi gamma); DN 5 (daun nangka yang diiradiasi gamma pada dosis 5 kGy); DN 7,5 (daun nangka yang diiradiasi gamma pada dosis 7,5 kGy); DN 10 (daun nangka yang diiradiasi gamma pada dosis 10 kGy). Data pengujian aktivitas biologis tanin diperoleh dari delapan perlakuan dan tiga pengulangan. Keempat perlakuan tambahan pada pengujian aktivitas biologis tanin diperoleh dari penambahan PEG pada keempat perlakuan sebelumnya. Data profil nutrien, serat, anti nutrien dan aktivitas biologis tanin dianalisis menggunakan rancangan acak lengkap (RAL). Pengujian dilanjutkan dengan duncan multiple range test (DMRT) jika terdapat perbedaan yang nyata. Analisis statistik dilakukan menggunakan program SPSS 22.0. Analisis korelasi dilakukan untuk mengetahui hubungan antara peubah aktivitas biologis tanin dengan profil nutrien, fraksi serat dan anti nutrien [21].

\section{HASIL DAN PEMBAHASAN}

\section{Profil nutrien dan serat}

Pengaruh iradiasi gamma terhadap kandungan nutrien dan fraksi serat daun nangka disajikan pada Tabel 1. Kandungan
$\mathrm{BO}$ dan abu pada daun nangka berbeda nyata $(\mathrm{P}<0,05)$, antara perlakuan iradiasi gamma dosis 5 - 10 kGy akan tetapi tidak berbeda dibandingkan dengan daun nangka tanpa iradiasi. Ketiga dosis iradiasi gamma tidak memberikan pengaruh terhadap kandungan PK, ADF dan hemiselulosa. Perlakuan iradiasi gamma pada dosis 5; 7,5 dan 10 kGy menurunkan $\quad(\mathrm{P}<0,05) \quad$ kandungan LK berturut-turut sebesar 57,82, 83,64 dan 97,09\% dari kandungan awal. Dosis $10 \mathrm{kGy}$ mampu menurunkan $(\mathrm{P}<0,05)$ kandungan NDF daun nangka sebesar 5,56\% dari kandungan awal.

Dosis iradiasi gamma $<10 \mathrm{kGy}$ tidak berpengaruh terhadap kandungan PK, namun sinar gamma dapat mengurangi kestabilan struktur peptida di dalamnya. Hal tersebut akan dijelaskan pada sub bahasan produksi gas total in vitro. Hasil penelitian ini sesuai dengan pendapat Taghinejad et al [22], Hassan et al [5], Zarei et al [23] dan Tresina et al [8] bahwa dosis iradiasi 2 - 25 kGy tidak memberikan efek yang nyata terhadap komposisi BO dan PK substrat. Iradiasi gamma akan lebih spesifik merubah komposisi asam amino bahan pakan sehingga dapat meningkatkan kecernaan protein [23]. Hasil yang kontradiktif dilaporkan oleh Osman et al [24] yang menjelaskan bahwa dosis 2 kGy sudah mampu meningkatkan kandungan PK Vicia faba L. Perbedaan hasil ini dapat dipengaruhi oleh perbedaan tingkat radiosensitivitas antar tanaman atau kondisi kelembapan materi ketika diiradiasi. Kedua hal tersebut adalah faktor utama yang mempengaruhi penetrasi radiasi gamma

Tabel 1. Profil nutrien dan serat daun nangka yang diiradiasi gamma

\begin{tabular}{lcccccccc}
\hline \multirow{2}{*}{ Perlakuan } & \multicolumn{7}{c}{ Profil nutrien dan serat (\% BK) } \\
\cline { 2 - 9 } & BO & Abu & PK & LK & NDF & ADF & Hemiselulosa & NFC \\
\hline DN & $85,78^{\mathrm{ab}}$ & $14,22^{\mathrm{ab}}$ & 13,08 & $2,75^{\mathrm{c}}$ & $50,01^{\mathrm{a}}$ & 36,81 & 13,21 & $19,95^{\mathrm{a}}$ \\
DN 5 & $86,95^{\mathrm{b}}$ & $13,05^{\mathrm{a}}$ & 13,07 & $1,16^{\mathrm{b}}$ & $50,06^{\mathrm{a}}$ & 37,13 & 12,94 & $22,65^{\mathrm{ab}}$ \\
DN 7,5 & $86,14^{\mathrm{ab}}$ & $13,86^{\mathrm{ab}}$ & 13,48 & $0,45^{\mathrm{ab}}$ & $50,17^{\mathrm{a}}$ & 37,23 & 12,94 & $22,05^{\mathrm{ab}}$ \\
DN 10 & $85,29^{\mathrm{a}}$ & $14,71^{\mathrm{b}}$ & 13,61 & $0,08^{\mathrm{a}}$ & $47,23^{\mathrm{b}}$ & 36,19 & 11,04 & $24,37^{\mathrm{b}}$ \\
SEM & 0,252 & 0,252 & 0,138 & 0,270 & 0,460 & 0,232 & 0,454 & 0,609 \\
\hline
\end{tabular}

Keterangan: a,b,c superskrip yang berbeda pada kolom yang sama menunjukkan perbedaan yang nyata $(\mathrm{P}<0,05)$. DN = daun nangka tanpa iradiasi gamma; $\mathrm{DN} 5$ = daun nangka yang diiradiasi gamma pada dosis $5 \mathrm{kGy}$; DN 7,5 = daun nangka yang diiradiasi gamma pada dosis 7,5 kGy; DN $10=$ daun nangka yang diiradiasi gamma pada dosis $10 \mathrm{kGy}$. $\mathrm{BO}=$ bahan organik; $\mathrm{PK}=$ protein kasar; $\mathrm{LK}=$ lemak kasar; $\mathrm{NDF}=$ neutral detergent fiber $; \mathrm{ADF}=$ acid detergent fiber $; \mathrm{NFC}=$ non fiber carbohydrate. $\mathrm{SEM}=$ standard error mean 
dalam merubah struktur kimia materi. Kelembapan materi akan berpengaruh terhadap kandungan air sampel sehingga membentuk radikal bebas setelah berinteraksi dengan energi radiasi [7]. Radikal bebas secara tidak langsung akan mempengaruhi perubahan komponen nutrien materi.

Iradiasi gamma secara bertahap menurunkan kandungan LK daun nangka, seiring dengan dosis yang semakin meningkat. Hal tersebut sesuai dengan penelitian Tresina et al [8] yang melaporkan bahwa kandungan LK Vigna aconitifolia cenderung semakin menurun setelah perlakuan iradiasi gamma $2-25 \mathrm{kGy}$. Hasil yang kontradiktif dilaporkan dalam penelitian Taghinejad et al [22] yang melaporkan bahwa perlakuan iradiasi gamma tidak berpengaruh nyata terhadap komposisi LK kedelai. Zarei et al [23] juga melaporkan bahwa dosis 5-20 kGy belum dapat merubah kandungan LK pada buah delima. Osman et al [24] bahkan melaporkan bahwa dosis iradiasi gamma $1 \mathrm{kGy}$ dapat meningkatkan kandungan LK Vicia faba L.

Kandungan NDF yang menurun pada iradiasi gamma $10 \mathrm{kGy}$ tidak diikuti dengan perubahan pada proporsi ADF dan hemiselulosa (Gambar 1). Penurunan fraksi serat mungkin terjadi pada komponen selulosa atau lignin. Hal tersebut karena fraksi NDF merupakan akumulasi dari hemiselulosa, selulosa dan lignin. Penurunan fraksi serat juga berpengaruh terhadap peningkatan fraksi NFC (Tabel 1) secara relatif. Hal tersebut akan berpengaruh terhadap peningkatan produksi gas dan kecernaan yang dibahas pada bab aktivitas biologis tanin. Penurunan fraksi serat setelah proses iradiasi juga dilaporkan oleh Tresina et al [8] yang menjelaskan bahwa dosis $2-25$ kGy mampu menurunkan Total Dietary Fibre pada legum Vigna aconitifolia. Hasil yang berbeda dilaporkan oleh Taghinejad et al [22] yang menjelaskan bahwa perlakuan iradiasi gamma tidak berpengaruh nyata terhadap komposisi NDF kedelai. Osman et al [24] dan Zarei et al [23] bahkan melaporkan bahwa iradiasi gamma dosis rendah dapat meningkatkan kadar serat kasar dan NDF sampel. Iradiasi gamma dosis $5 \mathrm{kGy}$ mampu meningkatkan ketersediaan hemiselulosa pada substrat jerami padi [25].

\section{Kandungan anti nutrien}

Kandungan total phenol dan tanin pada daun nangka yang diiradiasi gamma tertera pada Gambar 1. Kandungan total phenol keempat perlakuan tidak berbeda nyata dan berkisar antara 3,50 - 3,65 mg GAE/g. Kandungan total tanin pada daun nangka yang diiradiasi gamma pada dosis 5 dan 10 kGy berkisar antara 2,87 dan 2,88 mg TAE/g.

Penelitian ini membuktikan bahwa dosis iradiasi < 10 kGy belum mampu merubah komposisi kandungan total phenol dan tanin

Tabel 2. Efek penambahan PEG pada daun nangka terhadap profil fermentasi rumen dan kecernaan in vitro

\begin{tabular}{lccccc}
\hline \multicolumn{1}{c}{ Perlakuan } & $\mathrm{pH}$ & $\mathrm{NH}_{3}(\mathrm{mg} / 100 \mathrm{ml})$ & $\mathrm{EM}(\mathrm{kkal} / \mathrm{kg} \mathrm{BK})$ & VFA total $(\mathrm{mM})$ & KcBO $(\%)$ \\
\hline DN & 6,93 & $10,39^{\mathrm{abc}}$ & $1905,04^{\mathrm{a}}$ & $20,61^{\mathrm{a}}$ & $44,58^{\mathrm{a}}$ \\
DN 5 & 7,04 & $10,25^{\mathrm{ab}}$ & $1975,27^{\mathrm{a}}$ & $21,90^{\mathrm{a}}$ & $46,43^{\mathrm{a}}$ \\
DN 7.5 & 7,01 & $10,00^{\mathrm{a}}$ & $2029,57^{\mathrm{ab}}$ & $22,80^{\mathrm{ab}}$ & $48,00^{\mathrm{ab}}$ \\
DN 10 & 7,04 & $10,29^{\mathrm{ab}}$ & $2020,51^{\mathrm{ab}}$ & $22,60^{\mathrm{ab}}$ & $47,82^{\mathrm{ab}}$ \\
DN + PEG & 6,97 & $11,18^{\mathrm{bc}}$ & $2273,11^{\mathrm{c}}$ & $27,38^{\mathrm{c}}$ & $54,66^{\mathrm{c}}$ \\
DN 5 + PEG & 7,06 & $11,37^{\mathrm{c}}$ & $2283,80^{\mathrm{c}}$ & $27,58^{\mathrm{c}}$ & $54,88^{\mathrm{c}}$ \\
DN 7.5 + PEG & 6,97 & $10,49^{\mathrm{abc}}$ & $2365,16^{\mathrm{c}}$ & $28,97^{\mathrm{c}}$ & $57,19^{\mathrm{c}}$ \\
DN 10 + PEG & 7,01 & $10,10^{\mathrm{a}}$ & $2139,59^{\mathrm{b}}$ & $24,79^{\mathrm{b}}$ & $51,08^{\mathrm{b}}$ \\
SEM & 0,014 & 0,132 & 34,968 & 0,643 & 0,956 \\
\hline
\end{tabular}

Keterangan: a,b,c superskrip yang berbeda pada kolom yang sama menunjukkan perbedaan yang nyata $(\mathrm{P}<0,05)$. DN = daun nangka tanpa iradiasi gamma; $\mathrm{DN} 5$ = daun nangka yang diiradiasi gamma pada dosis $5 \mathrm{kGy}$; DN 7,5 = daun nangka yang diiradiasi gamma pada dosis 7,5 kGy; DN $10=$ daun nangka yang diiradiasi gamma pada dosis $10 \mathrm{kGy}$. PEG = polietilen glikol; $\mathrm{NH}_{3}=$ ammonia; $\mathrm{EM}=$ energi metabolis; $\mathrm{VFA}=$ volatile fatty acids $; \mathrm{KcBO}=$ kecernaan bahan organik. $\mathrm{SEM}=$ standard error mean 
pada daun nangka. Hasil yang berbeda diperoleh oleh [24], yang melaporkan bahwa dosis 1 kGy sudah mampu menurunkan kadar tanin dari biji Vicia faba L. pada dosis $>5 \mathrm{kGy}$, iradiasi gamma juga mampu menurunkan kandungan tanin terkondensasi pada buah delima [23]. Kontradiksi dengan penemuan dalam penelitian ini, Hassan et al [5] melaporkan bahwa iradiasi gamma dosis 2 kGy mampu meningkatkan kadar tanin kacang walaupun dalam taraf yang rendah. Janiak et al [9] dan Sari et al [7] menjelaskan bahwa iradiasi gamma dosis $5 \mathrm{kGy}$ mampu meningkatkan kandungan total phenol dan tanin pada daun teh. Pada dosis yang sama, paparan sinar gamma juga dapat meningkatkan kandungan tanin pada daun jambu monyet [6]. Pada dosis yang lebih tinggi (5 - $25 \mathrm{kGy}$ ), kandungan tanin pada legum juga dapat ditingkatkan [8].

Perbedaan hasil penelitian yang dilakukan dengan beberapa penelitian sebelumnya disebabkan oleh variasi efek radiasi pengion terhadap senyawa fenolik sampel. Behgar et al [26] menjelaskan bahwa penyebab hasil yang bervariasi dari perlakuan iradiasi gamma dapat disebabkan oleh perbedaan kemampuan ekstraksi dari masing-masing materi. Setiap materi bervariasi dalam merespon iradiasi melalui perubahan komponen selular dan pelepasan ikatan pada senyawa fenol yang tidak larut air. Gambar 1 menunjukkan bahwa ketiga perlakuan iradiasi gamma cenderung menurunkan kandungan phenol non tanin. Hal tersebut dapat direpresentasikan dari selisih kadar total phenol dengan total tanin. Tanin adalah golongan fenolik yang cenderung larut dalam air. Fenomena dalam penelitian ini perlu dijelaskan melalui riset lebih lanjut berbasis molekuler. Hal tersebut karena perubahan kandungan nutrien setelah paparan iradiasi gamma dapat disebabkan oleh perubahan molekuler materi serta pengaruh radikal bebas pasca radiasi [23].

\section{Produksi gas total in vitro dan aktivitas biologis tanin}

Aktivitas biologis tanin dapat ditentukan dari selisih antara produksi gas total perlakuan dengan/tanpa penambahan PEG. Gambar 2 menampilkan ilustrasi produksi gas in vitro daun nangka dengan/tanpa penambahan PEG. Perlakuan dosis iradiasi 7,5 kGy menghasilkan produksi gas total in vitro tertinggi $(\mathrm{P}<0,05)$ dari waktu inkubasi 3 sampai 24 jam. Produksi gas perlakuan tersebut juga tertinggi $(\mathrm{P}<0,05)$ setelah ditambahkan PEG. Dosis radiasi 7,5 dan 10 kGy menghasilkan produksi gas total yang lebih tinggi $(\mathrm{P}<0,05)$ dibandingkan daun nangka tanpa radiasi. Akan tetapi, setelah penambahan PEG, peningkatan produksi gas tertinggi dihasilkan oleh perlakuan kontrol

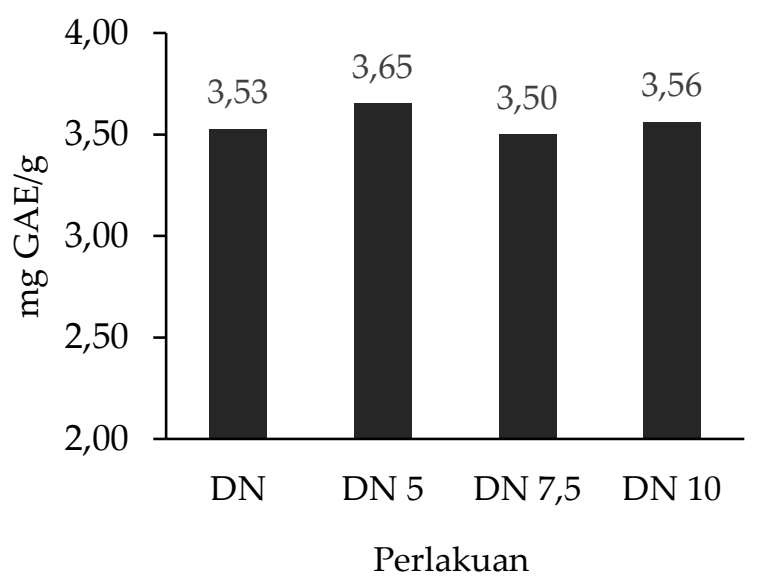

a.

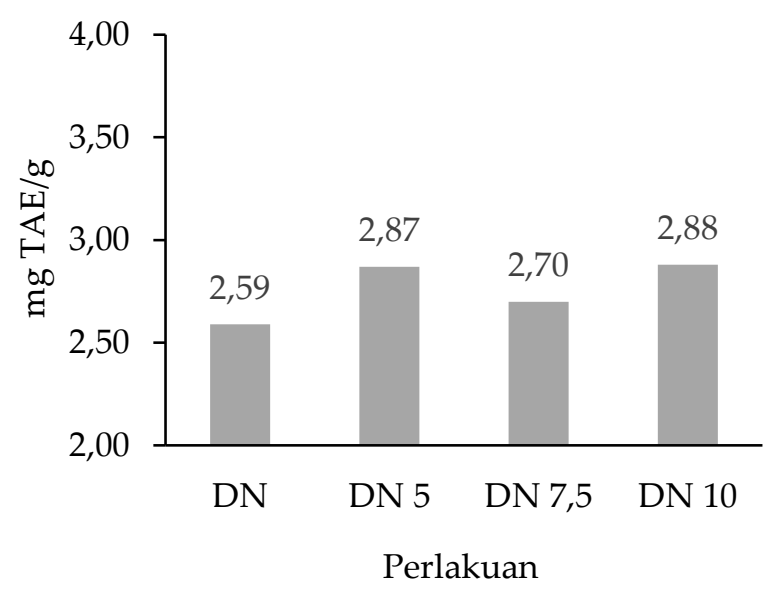

b.

Gambar 1. Kandungan total phenol (a.) dan total tanin (b.) pada daun nangka yang diiradiasi gamma. $\mathrm{DN}=$ daun nangka tanpa iradiasi gamma; DN 5 = daun nangka yang diiradiasi gamma pada dosis $5 \mathrm{kGy}$; DN 7,5 = daun nangka yang diiradiasi gamma pada dosis 7,5 kGy; DN 10 = daun nangka yang diiradiasi gamma pada dosis 10 $\mathrm{kGy} . \mathrm{GAE}=$ gallic acid equivalent; $\mathrm{TAE}=$ tannic acid equivalent 
sebesar 30,63\% (Gambar 3). Ketiga perlakuan iradiasi menghasilkan selisih produksi gas yang lebih rendah $(9,09-25,41 \%)$. Hal tersebut merepresentasikan bahwa perlakuan iradiasi gamma dapat menurunkan aktivitas biologis tanin pada daun nangka.

Getachew et al [4] dan Jayanegara dan Sofyan [3] menyatakan bahwa inkubasi in vitro dengan penambahan PEG akan menghasilkan representasi aktivitas biologis tanin. Nilai aktivitas yang dimaksud adalah adanya selisih produksi gas total antara perlakuan dengan/atau tanpa penambahan PEG. Polietilen glikol hanya bereaksi untuk menginaktivasi tanin yang terkandung dalam bahan pakan sehingga selisih produksi gaskumulatif hanya dipengaruhi dari perbedaan aktivitas tanin. Penurunan aktivitas biologis tanin sangat terlihat pada perlakuan iradiasi $10 \mathrm{kGy}$. Hal tersebut sesuai dengan penelitian Behgar et al [26] yang melaporkan bahwa dosis iradiasi gamma $>10$
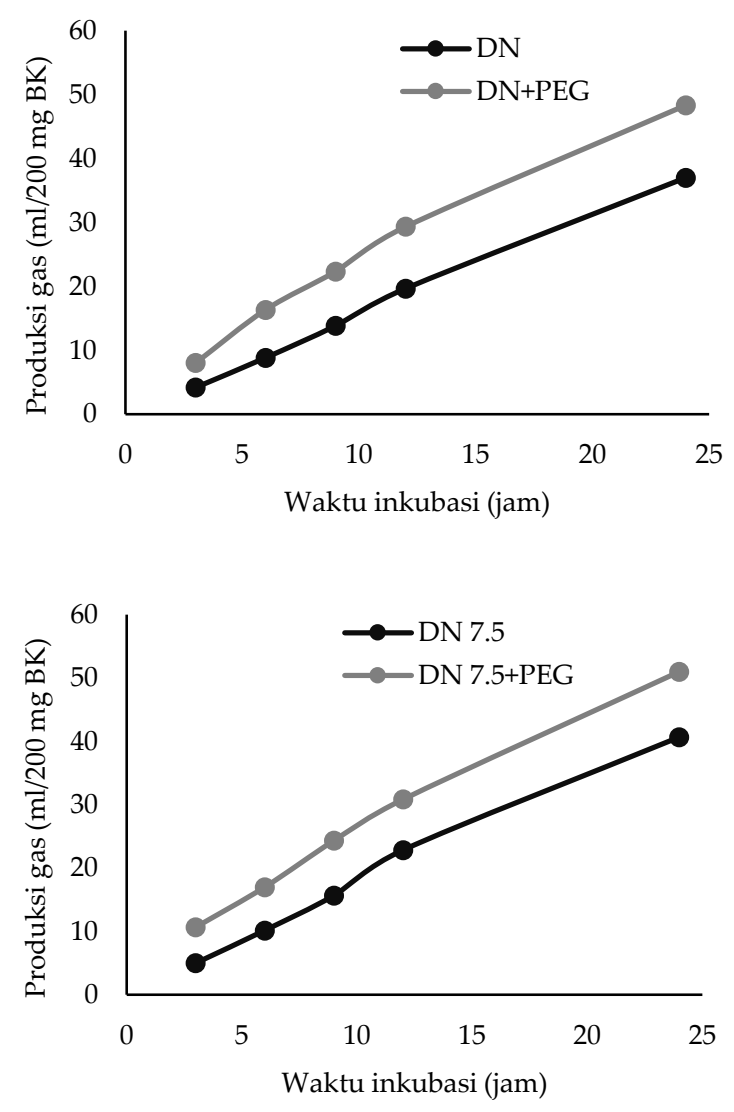

kGy akan menurunkan nilai ekuivalen tanin. Hal tersebut membuktikan bahwa iradiasi gamma dapat mempengaruhi kandungan kimiawi suatu bahan pakan. Perubahan ini bervariasi tergantung pada tingkat radiosensitivitas bahan tanaman. Pada daun nangka, dosis 5 kGy sudah cukup menurunkan aktivitas biologis tanin. Zarei et al [23] menyatakan bahwa kandungan dan aktivitas tanin terkondensasi akan semakin menurun setelah terpapar radiasi $>5 \mathrm{kGy}$.

Aktivitas biologis tanin yang semakin menurun juga dikonfirmasi dalam nilai produksi gas total. Kemampuan tanin daun nangka dalam berikatan dengan makronutrien semakin menurun sehingga dapat meningkatkan kecernaan nutrien yang ada didalamnya. Nilai produksi gas komulatif semakin meningkat seiring dengan perlakuan iradiasi gamma pada daun nangka. Osman et al [24] melaporkan bahwa tingkat kecernaan protein suatu bahan pakan akan meningkat
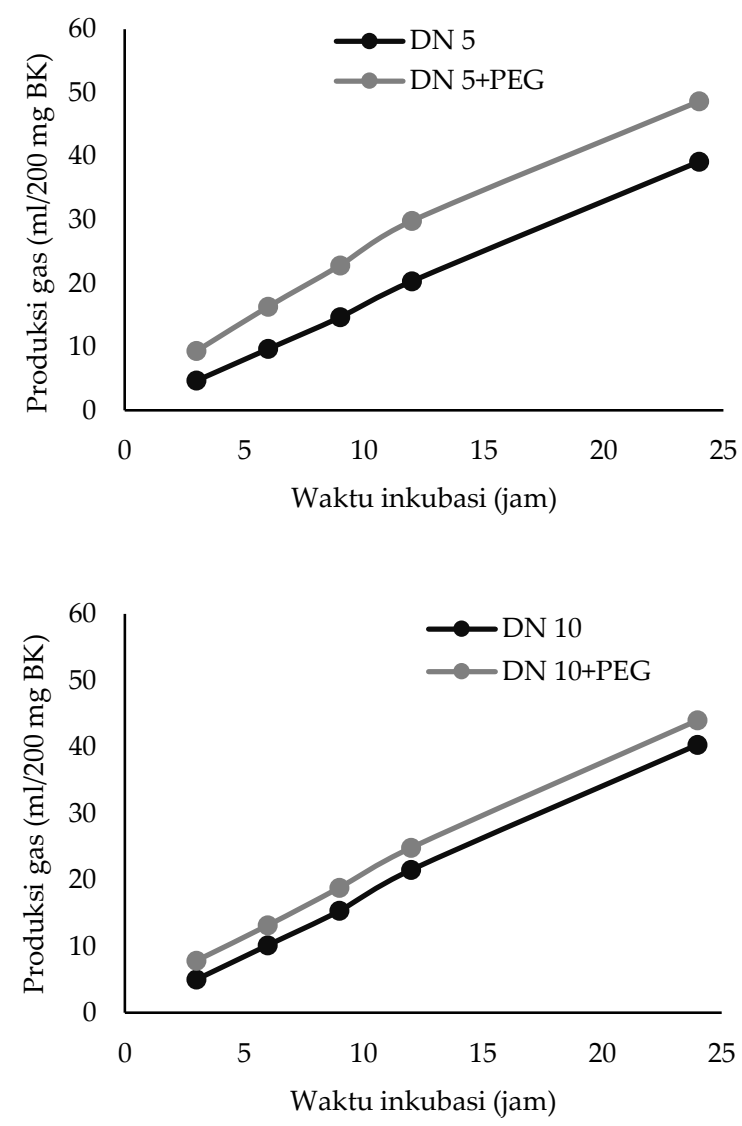

Gambar 2. Produksi gas in vitro daun nangka dengan atau tanpa penambahan PEG. DN = daun nangka tanpa iradiasi gamma; $\mathrm{DN} 5$ = daun nangka yang diiradiasi gamma pada dosis $5 \mathrm{kGy}$; DN 7,5 = daun nangka yang diiradiasi gamma pada dosis 7,5 kGy; DN $10=$ daun nangka yang diiradiasi gamma pada dosis $10 \mathrm{kGy}$. GAE = gallic acid equivalent; $\mathrm{TAE}=$ tannic acid equivalent . 
setelah bahan tersebut diiradiasi gamma pada dosis 1 kGy. Hassan et al [5] melaporkan hal yang kontradiktif, yaitu terdapat peningkatan aktivitas biologis tanin pada kacang yang diiradiasi gamma pada dosis 2 kGy. Hal tersebut direpresentasikan oleh rendahnya kecernaan protein setelah perlakuan iradiasi.

Produksi gas in vitro pada daun nangka yang diiradiasi gamma semakin meningkat karena pengaruh dari peningkatan fraksi NFC akibat perlakuan iradiasi. Fraksi NFC akan menyediakan sumber karbohidrat yang mudah didegradasi oleh mikroba rumen yang terinterpretasi pada produksi gas in vitro dan VFA total. Dugaan lainnya adalah bahwa 1) terdapat penurunan aktivitas inhibitor protein [22] selama iradiasi atau 2) terdapat pelemahan kestabilan ikatan protein sehingga mudah didegradasi mikroba rumen [24]. Taghinejad et al [22] lebih lanjut menjelaskan bahwa dosis $10 \mathrm{kGy}$ adalah dosis yang efektif untuk menginaktivasi anti nutrien berupa trypsin inhibitors (TI). Hal tersebut akan meningkatkan nilai nutrisi protein pada pakan.

\section{Profil fermentasi rumen dan kecernaan in vitro}

Profil fermentasi rumen dan KcBO sampel perlakuan dapat dilihat pada Tabel 2. Perlakuan iradiasi gamma dan penambahan PEG tidak berpengaruh terhadap nilai $\mathrm{pH}$.
Perlakuan iradiasi gamma juga tidak memberikan efek yang nyata terhadap konsentrasi $\mathrm{NH}_{3}$. Penambahan PEG mampu meningkatkan $(\mathrm{P}<0,05)$ nilai $\mathrm{EM}, \mathrm{VFA}$ total dan $\mathrm{KcBO}$. Peningkatan $\mathrm{KcBO}$ daun nangka setelah ditambahkan PEG berkisar antara 6,82 $-22,61 \%$.

Nilai $\mathrm{pH}$ dalam penelitian ini berkisar netral antara 6,93 - 7,04. Besaran nilai $\mathrm{pH}$ merepresentasikan pola degradasi mikroba rumen terhadap substrat pakan. Substrat dalam penelitian ini tergolong dalam hijauan pakan sumber serat sehingga akan mendukung perkembangan bakteri selulosa. Mcdonald et al [27] melaporkan bahwa nilai $\mathrm{pH}$ rumen $<6$ akan menghambat perkembangan bakteri selulolitik dan menurunkan degradasi serat pakan. Wahyono et al [2] menjelaskan bahwa nilai $\mathrm{pH}$ dengan substrat jerami kacang hijau yang disuplementasi tepung daun nangka berkisar antara 6,5 - 6,7. Wahyono et al [28] juga melaporkan bahwa substrat tanaman sorgum menghasilkan nilai $\mathrm{pH}$ kultur in vitro antara 6,62 - 6,79. Wanapat et al [29] melaporkan bahwa konsentrasi $\mathrm{NH}_{3}$ yang optimal pada kultur in vitro sistem tertutup adalah $5 \mathrm{mg} / 100$ ml. Akan tetapi, nilainya bergantung pada kandungan protein substrat serta tingkat kecernaannya di dalam cairan rumen-buffer. Hal tersebut karena $\mathrm{NH}_{3}$ adalah representasi degradasi protein dalam substrat pakan

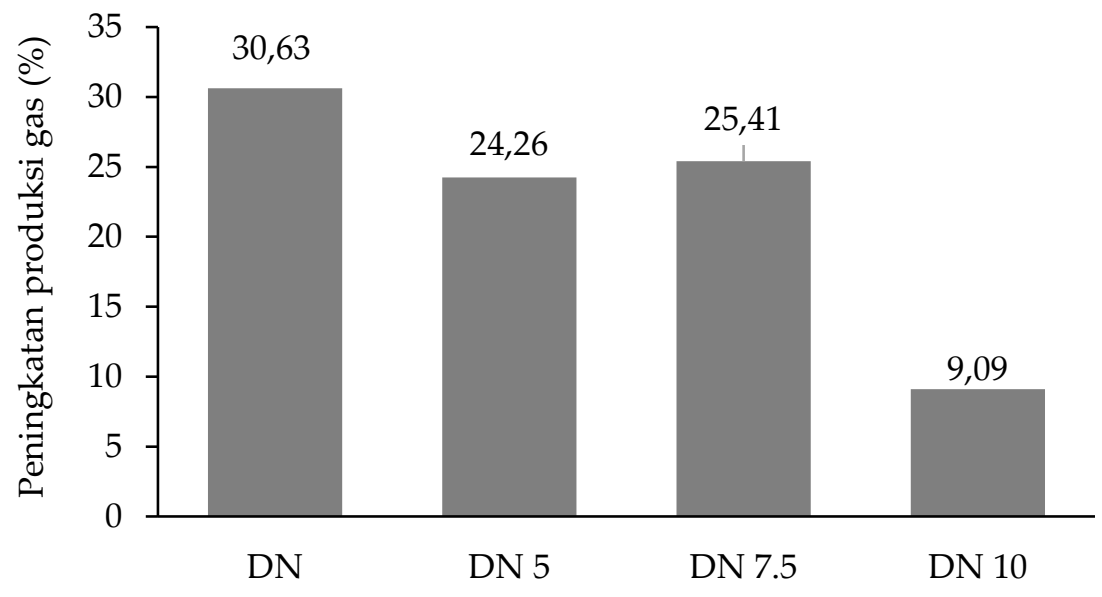

Gambar 3. Peningkatan produksi gas yang merepresentasikan aktivitas biologis tanin pada daun nangka yang diiradiasi gamma. $\mathrm{DN}=$ daun nangka tanpa iradiasi gamma; $\mathrm{DN}$ 5 = daun nangka yang diiradiasi gamma pada dosis $5 \mathrm{kGy}$; DN 7,5 = daun nangka yang diiradiasi gamma pada dosis 7,5 kGy; DN $10=$ daun nangka yang diiradiasi gamma pada dosis $10 \mathrm{kGy} . \mathrm{GAE}=$ gallic acid equivalent; $\mathrm{TAE}=$ tannic acid equivalent 
menjadi asam amino dan mengalami deaminasi untuk dimanfaatkan dalam sintesis protein mikroba [2]. Secara numerik, perlakuan penambahan PEG akan menghasilkan konsentrasi $\mathrm{NH}_{3}$ yang lebih tinggi dibandingkan tanpa penambahan PEG (kecuali perlakuan DN 10). Perbedaan nyata terlihat antara perlakuan DN 5 dengan DN $5+$ PEG. Hal tersebut merepresentasikan fungi PEG dalam menginaktivasi tanin. Jayanegara dan Sofyan [3] menjelaskan bahwa PEG akan berikatan dengan tanin karena memiliki afinitas yang lebih kuat dibandingkan dengan fraksi nutrien yang lain. Lebih lanjut lagi, dijelaskan bahwa nutrien-nutrien dalam substrat akan lebih tersedia bagi mikroba rumen sehingga berpengaruh terhadap nilai EM, VFA total dan KcBO.

Nilai EM, VFA total dan KcBO daun nangka cenderung meningkat secara numerik setelah perlakuan iradiasi. Hal tersebut merefleksikan produksi gas komulatif yang ditampilkan pada Gambar 2. Wahyono et al [28] melaporkan bahwa nilai VFA total adalah representasi dari proses fermentasi karbohidrat oleh mikroba rumen. Kondo et al [13] menyatakan bahwa nilai VFA total berkorelasi positif dengan produksi gas in vitro $(\mathrm{r}=0,96)$. Produksi VFA total yang dihasilkan dalam penelitian ini cukup rendah (20,61 - 28,97 mM). Jayanegara dan Sofyan [3] melaporkan bahwa kultur in vitro sistem tertutup cenderung berdampak negatif terhadap mikroba rumen, sehingga menyebabkan produksi VFA total rendah. Nilai EM, VFA total dan KcBO perlakuan DN 10 tidak berbeda nyata setelah ditambahkan PEG. Hal tersebut merefleksikan bahwa perlakuan iradiasi gamma dosis $10 \mathrm{kGy}$ justru menurunkan aktivitas biologis tanin secara signifikan.

\section{KESIMPULAN}

Perlakuan iradiasi gamma menurunkan kandungan LK daun nangka. Kandungan PK, total phenol dan total tanin tidak mengalami perubahan yang signifikan. Perlakuan iradiasi gamma pada dosis 5 - 10 kGy belum dapat meningkatkan aktivitas biologis tanin. Penemuan yang menarik adalah bahwa dosis iradiasi gamma 7,5 kGy mampu meningkatkan produksi gas komulatif dan kecernaan bahan organik in vitro daun nangka. Hal tersebut membuktikan bahwa dosis iradiasi gamma 7,5 kGy lebih mempengaruhi tingkat kecernaan nutrien dibandingkan dengan kandungan dan aktivitas biologis tanin pada daun nangka.

\section{KONFLIK KEPENTINGAN}

Tidak ada konflik kepentingan dalam penelitian ini.

\section{UCAPAN TERIMA KASIH}

Penulis mengucapkan terima kasih kepada Dr. Irawan Sugoro dan Ir. Firsoni, M.P. atas bantuan teknis di laboratorium. Penelitian ini menggunakan anggaran riset daftar isian pelaksanaan anggaran (DIPA) Pusat Aplikasi Isotop dan Radiasi (PAIR) BATAN tahun 2019.

\section{DAFTAR PUSTAKA}

1. Sasongko, W. T., L. M. Yusiati, Z. Bachruddin dan Mugiono. 2010. Optimalisasi pengikatan tanin daun nangka dengan protein bovine serum albumin. Bul. Peternak. 34(3): 154-158.

2. Wahyono, T., W. T. Sasongko, M. Sholihah, dan M. R. Pikoli. 2017. Pengaruh penambahan tanin daun nangka (Artocarpus heterophyllus) terhadap nilai biologis daun kelor (Moringa oleifera) dan jerami kacang hijau (Vigna radiata) secara in vitro. Bul. Peternak. 41(1): 15-25. Doi: 10.21059/buletinpeternak.v41i1.22450

3. Jayanegara, A. dan A. Sofyan. 2008. Penentuan aktivitas biologis tanin beberapa hijauan secara in vitro menggunakan 'Hohenheim gas test' dengan polietilen glikol sebagai determinan. Media Peternak. 31(1): 44-52.

4. Getachew, G., H. P. S. Makkar and K. Becker. 2000. Effect of polyethylene glycol on in vitro degradability of nitrogen and microbial protein synthesis from tanninrich browse and herbaceous legumes. Br. J. Nutr. 84: 73-83.

5. Hassan, A. B., E. E. Diab, N. S. Mahmoud, R. A. A. Elagib, M. A. H. Rushdi and G. A. 
M. Osman. 2013. Effect of radiation processing on in vitro protein digestibility and availability of calcium, phosphorus and iron of peanut. Radiat. Phys. Chem. 91: 200-202. Doi: 10.1016/j.radphyschem.2013. 05.008

6. Santos, G. H. F., E. B. Silva, B. L. Silva, K. X. F. R. Sena and C. S. A. Lima. 2011. Influence of gamma radiation on the antimicrobial activity of crude extracts of Anacardium occidentale rich in tannins. Brazillian J. Pharmacogn. 21(3): 444-449. Doi: 10.1590/S0102-695X2011005000045

7. Sari, B. L., D. P. Rahayu, D. Rohdiana, S. Nurlita dan P. S. Sahara. 2018. Pengaruh iradiasi sinar gamma terhadap kandungan flavonoid dan tanin total teh putih (Camellia sinensis L.) dan benalu teh (Scurulla atropurpurea BL . Dans). J. Kefarmasian Indones. 8(1): 1-9.

8. Tresina, P. S., K. Paulpriya, V. R. Mohan and S. Jeeva. 2017. Effect of gamma irradiation on the nutritional and antinutritional qualities of Vigna aconitifolia (Jacq.) Marechal: An underutilized food legume. Biocatal. Agric. Biotechnol. 10: 3037. Doi: 10.1016/j.bcab.2017.02.002

9. Janiak, M. A., A. Slavova-Kazakova, M. Karamac, V. Kancheva, A. Terzieva, M. Ivanova, T. Tsrunchev and R. Amarowicz. 2017. Effects of gamma-irradiation on the antioxidant potential of traditional Bulgarian teas. Nat. Prod. Commun. 12(2): 181-184. Doi: 10.1177/1934578X1701200210

10. de Camargo, A. C., S. G. Canniatti-Brazaca, T. M. F. S. Viera, M. A. B. Regitano-d'Arce and M. A. Calori-Domingues. 2011. Gamma radiation effects on peanut skin antioxidants. in: International Nuclear Atlantic Conference - INAC. Belo Horizonte, MG, Brazil: Associacao Brasileria de Energia Nuclear. pp. 24-28.

11. AOAC. 2005. Official Method of Analysis. $18^{\text {th }}$ ed. Association of Official Analytical Chemists. Arlington, VA, USA.

12. Van Soest, P. J., J. B. Robertson and B. A. Lewis. 1991. Methods for dietary fiber, neutral detergent fiber, and nonstarch polysaccharides in relation to animal nutrition. J. Dairy Sci. 74: 583-3597.

13. Kondo, M., M. Yoshida, M. Loresco, R. M. Lapitan, J. R. V. Herrera, A. N. D. Barrio, Y.
Uyeno, H. Matsui, T. Fujihara. 2015. Nutrient contents and in vitro ruminal fermentation of tropical grasses harvested in wet season in the Philippines. Adv. Anim. Vet. Sci. 3: 694-699. Doi: 10.14737/journal.aavs/2015/3.12.694.699

14. Cindrić, I. J., M. Kunštic, M. Zeiner, G. Stingeder and G. Rusak. 2011. Sample preparation methods for the determination of the antioxidative capacity of apple juices. Croat. Chem. Acta 84(3): 435-438. Doi: $10.5562 /$ cca1756

15. Makkar, H. P. S. 2003. Effects and fate of tannins in ruminant animals, adaptation to tannins, and strategies to overcome detrimental effects of feeding tannin-rich feeds. Small Rumin. Res. 49: 241-256.

16. Menke, K. H., L. Raab, A. Salewski, H. Steingass, D. Fritz and W. Schneider. 1979. The estimation of the digestibility and metabolizable energy content of ruminant feedingstuffs from the gas production when they are incubated with rumen liquor in vitro. J. Agric. Sci. Cambridge 93.

17. Ramos-Morales, E., A. Arco-Pérez, A. I. Martín-García, D. R. Yánez-Ruiz. P. Frutos and G. Hervás. 2017. Use of stomach tubing as an alternative to rumen cannulation to study ruminal fermentation and microbiota in sheep and goats. Anim. Feed Sci. Technol. 198: 57-66. Doi: 10.1016/ j.anifeedsci.2014.09.016

18. Conway, E. J. 1951. Microdiffusion Analysis and Volumetric Error. $3^{\text {rd }}$ ed. Crosby Lockwood and Sons Ltd. London.

19. Makkar, H. P. S. 2004. Recent advances in the in vitro gas method for evaluation of nutritional quality of feed resources. in: Assessing Quality and Safety of Animal Feeds. FAO Animal Production and Health Series 160. Rome: FAO. pp. 55-88.

20. Menke, K. H. and H. Steingass. 1988. Estimation of the energetic feed value obtained from chemical analysis and gas production using rumen fluid. Anim. Res. Dev. 28: 7-55.

21. Steel, R. G. D. and J. H. Torrie. 1960). Principles and Procedures of Statistics. McGraw. New York.

22. Taghinejad, M., A. Nikkhah, A. A. Sadeghi, G. Raisali and M. Chamami. 2009. Effects of gamma irradiation on chemical 
composition, antinutritional factors, ruminal degradation and in vitro protein digestibility of full-fat soybean. AsianAustralasian J. Anim. Sci. 22(4): 534-541.

23. Zarei, M., F. Kafilzadeh and P. Shawrang. 2016. In vitro gas production and dry matter digestibility of irradiated pomegranate (Punica granatum) seeds. Iran. J. Appl. Anim. Sci. 6(1): 31-39.

24. Osman, A. M. A., A. B. Hassan, G. A. M. Osman, N. Mohamed, M. A. H. Rushdi, E. E. Diab, E. E. Babiker. 2012. Effects of gamma irradiation and/or cooking on nutritional quality of faba bean (Vicia faba $\mathrm{L}$ .) cultivars seeds. J. Food Sci. Technol. DOI: 10.1007/s13197-012-0662-7

25. Firsoni, S. N. W. Hardani and T. Wahyono. 2019. Fiber content and relative feed value estimation of gamma irradiated rice straw. in: 9th Annual Basic Science International Conference, Malang: IOP Conference Series: Materials Science and Engineering 546 pp. 1-6. Doi: 10.1088/1757-899X/546/4/
042008

26. Behgar, M., S. Ghasemi, A. Naserian, A. Borzoie and H. Fatollahi. 2011. Gamma radiation effects on phenolics, antioxidants activity and in vitro digestion of pistachio (Pistachia vera) hull. Radiat. Phys. Chem. 80(9): 963-967. Doi: 10.1016/j.radphys chem.2011.04.016

27. Mcdonald, P., R. A. Edwards, J. F. D. Greenhalgh, C. A. Morgan, L. A. Sinclair and R. G. Wilkinson. 2010. Animal Nutrition. $7^{\text {th }}$ Ed. Pearson. London.

28. Wahyono, T., I. Sugoro, A. Jayanegara, K. G. Wiryawan and D. A. Astuti. 2019. Nutrient profile and in vitro degradability of new promising mutant lines sorghum as forage in Indonesia. Adv. Anim. Vet. Sci. 7(9): $810-818$. Doi: $10.17582 /$ journal. aavs/2019/7.9.810.818

29. Wanapat, M., S. Kang and K. Phesatcha. 2013. Enhancing buffalo production efficiency through rumen manipulation and nutrition. Buffalo Bull. 32(1): 258-275. 